\title{
The sound of literature in musical transla- tion, as illustrated by Benjamin Britten and Peter Grimes ${ }^{1}$
}

\author{
Marta Mateo*
}

\section{Introduction: Literature, Opera and Translation}

The connection between literature and music is old and complex. The two arts were in fact one in ancient times: Brown reminds us that the Iliad was originally chanted while, throughout most of history, music has been vocal; instrumental music became an important art just a few centuries ago, and "[o]nly then did non-literary music and non-musical literature become parallel arts" (Brown 2000, p. 282). Mousiké, the art of the Muses in ancient Greece, involved the unity of song - therefore music and poetry - and dance; and, although literary genres gradually became independent art forms, the mixture of text, music and dance has really been no exception, as operas, stage and film musicals, and songs of various styles can testify. Opera, on which our attention will be focused in this article, is in fact a form of drama and its definition often includes a reference to literary art forms - as in, for instance, the Spanish Diccionario de Música y Músicos: "Musical work in which various arts are blended: music, poetry, theatre, dance" $^{\prime 2}$ (1996 edition, quoted in Arkus 2003, v. 37, p. 12 - my translation). Indeed, the originators of opera in the 16th century seemed to consider its

\footnotetext{
${ }^{1}$ The work for this article was carried out during a research stay at the University of Exeter (United Kingdom), from 1st February to 31st July 2018, thanks to a grant financed by the Spanish Ministerio de Educación, Cultura y Deporte, as part of its Programa de Estancias de movilidad de profesores e investigadores seniores en centros extranjeros de enseñanza superior e investigación, incluido el Programa Salvador de Madariaga 2017 (Ref. PRX17 / 00217).

${ }^{*}$ Instituto Cervantes at Harvard University / Universidad de Oviedo.

2 “Obra musical donde se conjugan diversas artes: música, poesía, teatro, danza.”
} 
main function "the declamation of poetry", while some of the later and greatest composers, like Mozart, Verdi and Britten, seem to have clearly acknowledged its "close ties with literature" in their works, as Corse states (1987, p.12).

A clear and important confluence of the two arts can be found in the role literature has played as an inspiration for opera librettos and for good lyrics in other musical genres. A considerable number of opera pieces have their origins in literary masterpieces (Schmidgall 1977, p. 23), and many of these "literary" operas can be counted among the greatest in the repertoire. Composers like Verdi and Puccini seem to have been keenly aware not just of the dramatic nature of the genre but also of the important role the libretto plays in the success of an opera: both composers carefully chose, as sources for their musical dramas, plays which had already been successful on stage and had therefore put their theatricality to the test, as has been studied by Salzman and Desi (2008), who maintain, furthermore, that in the historical development of the genre "it was the libretto that led to new types of opera and music theater and which determined the first success or failure of new work" (2008, p. 84), and the contribution of literary texts to this should not be ignored.

As for translation, it has not only enabled the understanding of musical texts composed in foreign tongues but it has frequently served an essential cultural and artistic function, not just for literature but for various musical systems - even though translators' "roles as cultural mediators" in music (Low 2013, p. 77) is not so well-known or acknowledged. For instance, in his study on "Early English translations of Italian opera", Degott (2010) recalls how those translations which were provided to opera audiences when Italian opera settled in England in the first half of the 18th century, were not just an aid to follow the plots but were meant to disprove the widespread assumption regarding the poor quality of libretti, also passing "comment on the social, political or aesthetic issues that were implicitly or explicitly raised by the works in question" (2010, p. 187).

When music/opera, literature and translation are studied together, some questions arise which prove challenging and often controversial: how is meaning transposed from literature to music?; what is the role of a liter- 
ary text and the music it has been set to in the creation of meaning in a song piece?; what does translation consist of when dealing with musical texts in which literature and music go hand in hand? - as Newmark put it in his last article, "[ $\mathrm{t}]$ he process of translation becomes multilayered when wordmusic relations are concerned" (2013, p. 61). We can also ask how successful musical transpositions of literary texts are or, in Desblache's words, "[w]hat salient issues are then visible in foreign translations of the libretti?" (2008, p. 105). This article will reflect on some of these interesting and complex questions relating to the connection between literature, opera and translation by turning our attention to Benjamin Britten, whose work Peter Grimes will serve to illustrate, first, the process of translation as transmutation - from literature into opera, and then that of translating vocal music into a different language and communication channel.

\section{Literature as opera, with a focus on Benjamin Britten's work}

Vocal music has frequently fed on literary texts from various genres, cultures and periods. Many of its masterpieces are actually the result of journeys with very diverse origins. Moreover, the world of opera has often run parallel to changes and developments in literature: for instance, the romantic movement and the new interest in folklore characterizing literature in Europe at the end of the 18th century provoked a similar trend in opera in the following century (Salzman and Desi 2008, p. 89). Some literary systems have been particularly productive in opera at certain times: thus, Verdi's Rigoletto and La traviata, Puccini's Tosca and La Bohème, Bizet's Carmen, Massenet's Thaïs or Poulenc's Dialogue des Carmélites are all based on French literary texts (Rosmarin 1999, p. 10); and Greek tragedy and Roman poetry have been the object of important operatic versions in various periods, such as Purcell's Dido and Aeneas, Cherubini's Medea, Strauss's Elektra, Orff's Antigone, or Stravinsky's Oedipus Rex. In actual fact, most of the great world dramatists have seen their works turned into operas: from Euripides, Sophocles and Aristophanes, through Shakespeare, Jonson and Racine, to Ibsen, Chekhov, Wilde or Miller; so have novelists such as Dostoevsky, Flaubert or Tolstoy (see Salzman and Desi 2008, p. 86; and Schmidgall 1977, p. 368-9). And some literary characters seem to have attracted attention at 
particular periods, like Don Quixote, which was the object of at least two opera versions by English composers in the 19th century, Sir George Alexander Macfarren (1846) and Frédéric Clay (1876) (Arkus 2003, v. 37, p. 10$11)$.

As can be observed, many of these journeys across genres also take the texts across linguistic and cultural boundaries. Some composers have been particularly receptive of foreign works: Verdi, for example, who commonly resorted to works by Shakespeare, Victor Hugo and Schiller (see Corse 1987, p. 11). A more recent example is the American composer Thomas Pasatieri, who has chosen the literary sources for his librettos from a really wide range of texts: by Unamuno, Molière, Chekhov and Henry James and a 14th-century Portuguese story (see Schmidgall 1977, p. 368).

And in these comings and goings, English literature has been particularly dynamic: plays, narrative texts and poetry from different writers and periods have been turned not just into operas but also into stage/film musicals and/or songs of various types. ${ }^{3}$ Shakespeare, for instance, provided inspiration not just for Verdi - his late masterpieces Otello (1887) and Falstaff (1893) (the latter based on the famous character in The Merry Wives of Windsor and Henry IV), as well as his earlier Macbeth (1847) - but for various other composers, among them Benjamin Britten, whose Midsummer Night's Dream (1960) was also inspired by the bard's popular character Sir John Falstaff - itself the object of another piece in the 20th century, Vaugham William's Sir John in Love (1946).

Indeed, among 20th-century composers who set their eyes on literature for their operas, Benjamin Britten occupies a special place, since "[n]o one in this century has proved as perspicacious and successful a musical translator of literature as [this composer]" (Schmidgall 1977, p. 368). He used texts by English-language writers and some foreign ones too, and, like Mozart or Verdi, he "emphasized the literary qualities of the texts [he] adapt[ed]" (Corse 1987, p. 11). The libretto of his first opera, Paul Bunyan (1941), was written by W.H. Auden and inspired by American stories from

\footnotetext{
${ }^{3}$ See Arkus's excellent overview of British opera from Purcell to Britten (2003, v. 37 \& v. 38) and the earlier and valuable studies by Weisstein, “The Libretto as Literature" (1961, in Bernhart 2006, p. 3-15), and by Schmidgall (1977).
} 
oral tradition (Suárez Lafuente 2011, p. 12). He resorted to another, earlier, English poet, George Crabbe, for his next opera, Peter Grimes (1945), as will be discussed in the next section of this article. These were followed by The Rape of Lucretia (1946), which was directly based on a French play by André Obey but whose topic can be traced back through various texts in Western literature, among them a poem by Shakespeare (Suárez Lafuente 2011, p. 12). A short story by another French writer, Maupassant, provided the basis for Albert Herring (1947); while for his next pieces Britten resorted to English language literature: The Beggar's Opera (1948), an adaptation and arrangement of the well-known 18th-century satirical ballad-opera by John Gay; Billy Budd (1951), after a novel by Melville; The Turn of the Screw (1954), adapting the famous novella by Henry James, who was a fertile source of inspiration for 20th-century opera composers (Desblache 2008, p. 105 and Halliwell 2005); and, as mentioned above, A Midsummer Night's Dream (1960). He would go back to Henry James for his last highly innovative opera, Owen Wingrave (1971), one of the rare operas commissioned for television, which was broadcast on BBC2 in May 1971 (Desblache 2008, p. 109). Soon after that, he composed a major piece, Death in Venice (1973), once more turning his eyes to a foreign literary system, to adapt the wellknown short novel by one of the greatest contemporary German writers, Thomas Mann.

This list clearly reveals Britten's care for the quality of the texts he chose, not just for his opera librettos but also for other pieces of vocal music he composed. As Low puts it,

\footnotetext{
Britten's horizons were [wide]: he viewed as fair game any poem written since 1400, even in non-standard English. Among the poets he set at least once are: William Shakespeare, John Donne, Robert Herrick, John Milton, William Blake, William Wordsworth, Samuel Taylor Coleridge, Percy Bysshe Shelley, John Keats, Alfred Tennyson and Thomas Hardy. This impressive list shows him to be a connoisseur of poetry, and indeed a champion of England's poetic heritage. Besides, he set many lesser-known poets writing in English, including some Scots, notably Robert Burns, and some Americans (2013, p. 69).
}

These "wide horizons" can also be observed in what some consider his greatest musical work (see, for instance, Newmark 2013, p. 62), his War 
Requiem, a mass for the dead in war composed for the consacration of the new Coventry Cathedral (after the old one had been destroyed by World War II bombing), in which he interspersed English poems by Wilfred Owen with the traditional Latin texts of a Requiem mass.

Like other composers, Britten also used his creations to reflect on the relationship between words/literature and music, something which is crucial to all operas. His Death in Venice explores the trouble its hero, a professional writer, has in using language - while in another opera, Paul Bunyan, Britten plays with the limitations of singing as communication (Wiebe 2015, p. 146). According to Corse, "the most self-conscious operas" have always focused on the words-music relationship, choosing subjects with a strong presence of language in which humans' use of and attitude towards language "becomes an issue in the drama itself" (1987, p. 149, p. 12). In Death in Venice, "Britten combined music, language, and visual imagery to an unusual degree in order to explore some basic questions about the human ability to communicate, as well as the impulse to supress the unconscious"' (1987, p. 149).

Finally, Britten's production also serves to illustrate other minor instances of the connection between literature and music/opera: interesting cases of intertextuality occurring across genres, such as musical quotations in literary texts or literary quotations in musical texts. A good example of the latter is provided by his opera The Turn of the Screw, in which a line from a poem by W.B. Yeats (The Second Coming [1919]), "The ceremony of innocence is drowned", is uttered by the two ghosts and echoed by the governess so as to evoke the evil powers of the former (Desblache 2008, p. 115 ) and probably to reveal the key to this work.

\section{Translation as transmutation}

\section{Choosing and adjusting the literary text}

Giuseppe Verdi once said "Anything can be set to music, true, but not everything will be effective" (quoted in Schmidgall 1977, p. 3). Indeed, some literary texts have proved problematic in terms of musical adaptation, while others, as Weisstein put it, "seem to have lost their status as litera- 
ture, the musical versions having, in a manner of speaking, superseded their literary antecedents. Such is the triumph of music in opera" ([1961] in Bernhart 2006: 4). This has been the case, for instance, with Oscar Wilde's Salomé, which is now a staple of the world's operatic repertoire in Richard Strauss's musical version while it is not so commonly performed in its original form.

What makes a literary text suitable for libretto adaptation? Schmidgall suggests that the best way to reflect on this issue is to think of writers whose style we would hardly conceive of in operatic form, such as "Henry Fielding, Laurence Sterne, Anthony Trollope, Jane Austen, Charles Dickens, George Bernard Shaw, and Virginia Woolf", whose artistry may be said to be "descriptive and analytical, rather than lyrical and expressive" (1977, p. 14). What turns these writers' literary works "unoperatic" is, in Schmidgall's view, that "theirs is a theatre of words, whereas opera requires a theatre of action, emotion, engagement, movement and spectacle" (p. 14). This is connected to other essential, often criticized, features of opera, its unreality and need for exaggeration, magnification, expressive intensity: "music seeks emotions, characters, and situations suitable to amplification" (p. 11), it cannot express abstract concepts or intellectual states, which is why Hamlet will probably never make a good opera. It is as if the characters' feelings and actions prompted them "to 'break into' vocal utterance", also in Schmidgall's words (p. 365). ${ }^{4}$

These implausible works in which characters are made to sing no matter what they are communicating, from the banal to really vital issues in their lives, truly require a great suspension of disbelief on the part of the audience - not to mention the many cases in which an opera libretto is full of far-fetched situations, stereotyped characters, unconvincing motives or highly melodramatic plots (Rosmarin 1999, p. 8). But it is the genre's aesthetic and emotional power that fully compensates for its absurdities in the

\footnotetext{
${ }^{4}$ W.H. Auden put it this way: "[T] he librettist need never bother his head, as the dramatist must, about probability. [...] A good libretto plot [...] offers as many opportunities as possible for the characters to be swept off their feet by placing them in situations which are too tragic or too fantastic for 'words'. No good opera plot can be sensible, for people do not sing when they are feeling sensible" (Auden 2008 [1949-55]: 300).
} 
eyes of opera lovers (Schmidgall 1977, p. 10). An excess of realism may in fact be inimical to the genre.

All this implies that it is not necessarily an outstanding quality in a literary text that will make a good libretto. A case in point are some of Shakespeare's major plays, like The Tempest or King Lear, which have proved rather problematic for opera composers, as Schmidgall recalls (1977, pp. 3-4). ${ }^{5}$ Sometimes, however, a composer's style, personality and talent seem to be the perfect fit for a particular literary text and produce an operatic masterpiece, as Schmidgall considers was the case with Britten's version of A Midsummer Night's Dream (1977, p. 5). ${ }^{6}$

Whatever the text and its literary quality, it will have to be submitted to a process of adjustment during the musical setting. We could refer to this process as one of 'adaptation', 'transmutation', 'transposition', or even 'translation' in a wide sense. Jakobson's qualified term intersemiotic translation (or 'transmutation'), occurring when there is "an interpretation of verbal signs by means of signs of nonverbal sign systems" (2000 [1959], p. 114) is still useful and valid too, to describe such cases as when a literary text becomes a painting or a piece of music. ${ }^{7}$

\footnotetext{
${ }^{5}$ One of the reasons this researcher suggests to explain why both the French composer Emmanuel Chabrier and Mendelssohn failed in their effort to adapt The Tempest in the 19th century is the great variety of levels Shakespeare's play operates on - "autobiographical, political, magical, symbolic, philosophical", probably too numerous to be re-fitted together once music was added (1977, p. 4). An excess of themes and intricacies is also quoted as the reason why, after fifty years of work on King Lear, Verdi gave up his plan of a Re Lear (p. 19).

${ }^{6}$ And some writers appear rather congenial to operatic adaptation: Desblache attaches Henry James's appeal for composers to his liking for the novella, a genre which, being shorter than the novel, lends itself to adaptation (into both opera and cinema) (2008, p. 105-106); as well as to his style of writing, which she defines as "essentially suited to operatic expression because it suggests as much as it tells, because it prioritises textual ambiguity over a single meaning and because part of its beauty is to leave space for silence, for the untold, for the unknown" (p. 121). On the other hand, much of 20th-century drama, which focused "on the tedium and purposelessness of existence", in "a climate of indirection and metaphysical complexity" and with deliberately mediocre protagonists, can hardly be imagined as suiting the "grand style, the elevated gesture, and resounding utterance" which make an engaging opera libretto, resorting to Schmidgall's words once more (1977, p. 362, p. 364, p. 370, respectively). ${ }^{7}$ An example of the former would be the famous oil painting featuring Romeo and Juliet in the balcony scene by Frank Bernard Dicksee (1884), while the latter could be represented by Prokofiev's ballet Romeo and Juliet.
} 
Nevertheless, Peter Newmark makes a further distinction between these types of transmutation and song settings, which is highly relevant to the present study:

\begin{abstract}
Whereas intersemiotic translation transfers content from one medium to another, such as sculpture to painting, or music to painting, [...], in song settings [...] I read an inverted form of intersemiotic relations; something from the text is transferred to the music, and then somehow the converse takes place (2013: 62).
\end{abstract}

It can also be added that, precisely because vocal music (of whatever genre) consists of (sung) verbal text, Jakobson's intersemiotic translation can overlap with the interlingual category. Many of the examples mentioned in the previous section are both the result of adapting a literary text to a musical setting and of "translation proper" - as Jakobson defined the category of interlingual translation.

The process through which a literary text (from a foreign language or not) becomes linked to a musical score corresponds to what Calvin Brown, in his study of the types of relationship between music and literature (2000 [1984]), called Combination, since a verbal text is combined with a musical setting, producing, e.g., a song or an opera, the two most typical forms, or other types such as a cantata, an oratorio, a melodrama or incidental music for a play. This type of linkage involves a series of problems derived from "the collaboration of or struggle for dominance between words and music" (Brown 2000 [1984], p. 288).

The product of that is inevitably a compromise which depends on factors such as the composer's musical style, the language chosen for the libretto - since languages will present different problems in song setting or the way in which the verbal text functions in vocal music. In opera librettos, in particular, the weight of the communicative and aesthetic roles of language is quite different from their significance in literary texts: as Corse puts it, "[i]n opera, the aesthetic function of language is reduced in the text because it is redistributed to the music" (1987, p. 15), so the communicative function of the libretto is heightened making it "lean toward directness and simplicity of language" (p. 15). This means that, when a lit- 
erary text is turned into a libretto, much of what makes it literary is removed from it: "Metaphor is reduced, subplots are cut, and characterization is minimized" (p.14). The aesthetic function is therefore created by the music and what remains of that literariness. It is as if the "amplifying power of music" (Schmidgall 1977, p. 9) required the libretto to be first condensed ${ }^{8}$ - even though, admittedly, repetitions are not only also frequently called for, in order to fill in a musical phrase, but are actually allowed as a common feature of vocal music.

The considerable reduction in the amount of text needed in musical drama (not just opera) explains why novels tend to be difficult to condense and why certain literary texts have never been adapted for opera or stage musicals - apart from the above-mentioned problems posed by some of Shakespeare's best plays, Desblache informs us that Britten, for instance, contemplated, but eventually abandoned, the idea of composing an opera on Tolstoy's Anna Karenina (2008, p. 106). Nevertheless, according to this researcher, the librettos of Britten's operas tend to be considerably longer than those of many standard works from the repertoire, a characteristic she assigns to the composer's close collaboration with his librettists in the creation of his works (Desblache 2008, p. 109-110).

Other important factors which affect the process of transmutation into musical drama are the vital role of rhythm in music, or artificial conventions established in opera, such as (briefly, and borrowing from Weisstein, in Bernhart 2006, pp. 8-41): the possibility of simultaneity (having several characters express themselves at the same time, something unthinkable - or very rare - in spoken drama); a different notion of time, which does not always seem to flow horizontally but is frequently interrupted by moments of introspection which replace, or are combined with, action in ensembles; or the fact that lyric and dramatic moods fluctuate in the act, the basic unit around which emotions crystallyze. Most important in the process, of course, will be the adjustment of the verbal text to the musical setting, bearing in mind the need for the quality and quantity of

\footnotetext{
${ }^{8}$ Rosmarin explains this neatly (1999, p. 10): “The librettist simplifies, tightens and in some cases reworks the original structures of the literary texts in order for the music to make its maximum dramatic impact."
} 
speech sounds in the former to match, and be congenial to, the notes in the latter.

\section{From poetry to opera: Peter Grimes}

Benjamin Britten's opera Peter Grimes, one of his most successful, will serve as a good example of the process of musical transmutation, illustrating the issues discussed so far. It was the first piece the composer based on a literary work, the early 19th-century English poem The Borough by the poet George Crabbe (1754-1832), and it is particularly interesting because it also raises the issue of the relation between words and music. In his works in general, the British composer did not only take great care of the choice of texts but he also highlighted the importance of librettos in his musical settings, ensuring, for instance, that the verbal text was never overshadowed by the instrumental parts and that its meaning was never obscured with high notes, as well as insisting on the singers' correct enunciation for the sake of the intelligibility of the sounds (Low 2013, pp. 70-71). Various of his works, like this one, in which the problems of language to communicate our deeper meanings loom large, show how he "[used] the indefiniteness of music to awaken the audience to the indefiniteness of language", as Corse so aptly expressed it (1987, p. 150).

Peter Grimes was premièred in London in 1945 and it was an unprecedented and historical success for 20th-century British opera, stimulating the development of English musical drama. It earned Britten international fame, being immediately performed abroad to enormous critical acclaim and becoming the first English opera, after Purcell's Dido and Aeneas, to be part of the standard opera repertoire. With this work, Britten indeed hoped to repair the "scarcity of modern British operas" (quoted in Wiebe 2015, p. 151), and its success has variously been attached to its dramatic coherence, realism and emotional directness (pp. 150-152) ${ }^{9}$, as well as to

\footnotetext{
${ }^{9}$ According to the reviewer for Tempo, other works by Benjamin Britten had already enjoyed "unusual success" before 1939. But he adds: "That an English opera should appear on a foreign stage at all is a rare enough event. That it should then proceed to repeat its original London success is surely unparalleled" (Tempo 1946, p. 17).
} 
"the innate dramatic interest of its hero [and] to its polished musical score" (Spiegelman 2008, p. 1).

The libretto was written by the playwright and literary critic Montagu Slater, but, as Slater himself once said, it was Britten that provided the idea for the character and the story (Spiegelman 2008, p. 21). In fact, the idea originally hit the composer while in exile in the USA with his partner the tenor Peter Pears, when he came upon a radio talk with E.M. Forster published in The Listener in 1941, in which the English novelist and critic discussed the work by George Crabbe. Back in England, Pears would help Britten sketch the outline for an opera based on Crabbe's The Borough. He would actually be the first Grimes on stage, in that succesful première at the Sadler's Wells Theatre.

In The Borough (1810), set in his (and Britten's) native town Aldeburgh, on the east coast of England, Crabbe describes life in a fishing town at the turn of the 19th century, through a poem of quasi epic length. A naturalist, a clergyman and a surgeon, Crabbe depicted provincial life with crude and unsentimental realism, combining it with a sort of psychological analysis and moral criticism of his characters' actions. His account of Peter Grimes is the 22nd letter, which contains 375 lines and appears in a section called "The Poor of the Borough", also including a letter (n. 20) devoted to "Ellen Orford", with 337 lines. These are the two extracts which Slater used to create his libretto.

Britten was captivated by George Crabbe's evocative language, realistic characters and social criticism, and he worked closely with Montagu Slater to produce a libretto consisting of a prologue and three acts, each of them divided into two scenes, all of which are separated by a symphonic interlude, serving both to establish the continuity of the acts and as an introduction to the following dramatic unit. Through the story of the violent and solitary fisherman, who has seen several of his apprentices die and has thus fuelled the townspeople's suspicions, Britten's opera explored themes such as: the contradictions of human nature, the outsider perceived as a threat by his own community, the issues of truth and falsehood, rumours and gossip, secrecy and silence, love and friendship, violence, children's conditions, morality, or the impact of the sea on rural people's lives. 
Slater and Britten not only modernized the rhythm of Crabbe's verse but also, more importantly for our purposes, they adapted Crabbe's poem to the dramatic and musical needs of the opera genre and modern audiences' taste (Suárez Lafuente 2011, p. 17). Let us see some of the most relevant changes in this regard:

\section{a. Condensation of the original text}

The opera condensed letter 22 from Crabbe's poem, doing away not only with everything concerning Peter Grimes's childhood (his animosity towards his father, his rebellious character, his liking for drink, gambling and theft, etc.) but also with the part narrating the deaths of the first apprentices. In fact, the libretto starts in medias res, with a Prologue in which Grimes is being tried for the death of his second apprentice and is acquitted for lack of evidence, arousing, however, his townspeople's suspicions and mounting accusations which will accompany him till the end of the opera (and his own). Crabbe's four apprentices are reduced to three in the opera, but we only see the last one of them on stage - the stories of the other two, however, being recalled by Peter in one of Britten's famous lyrical recitatives, "In dreams I've built myself some kindlier home" (II.ii), and in Peter's last mad soliloquy “Steady. There you are. Nearly home!” (III.ii).

\section{b. Variety of themes and characters}

Conversely, the limited number of themes, "which made the atmosphere of the original poem claustrophobic and macabre" (Suárez Lafuente 2011, p. 17 - my translation), is expanded in the libretto, through new situations, dialogues and characters which are introduced to adjust it to the requirements of its dramatic nature. Characters become individualised, and two common themes of the opera genre are incorporated through two of them: friendship, which had no place in Crabbe's original poem and is here incarnated in Captain Balstrode, and love - "nowhere to be seen in Crabbe's poem" either (Bewell 2005, p.643), and embodied by Ellen Orford's character, who Slater and Britten drew from letter n. 20 of the literary text. The librettist does not develop the widowed teacher's sad and tragic story narrated by Crabbe, but he turns her into a central figure in the opera by mak- 
ing her fall in love with Peter. The protagonist in turn makes Ellen the object of the dreams he cherishes of a future respectable life, in which he would be married to her and thus gain the Borough's respect.

\section{c. Changes in tone and characterization}

As happens with all adaptations, the opera also shows changes which respond to the composer's and librettist's personal view of the story. Some of the most remarkable changes are the following:

-Despite its harrowing story, the overall tone of the opera is somewhat different from that of the poem, since the ambiguity and contradiction injected by Britten and Slater in the protagonist's characterization, the introduction of love and friendship which make him less of a solitary figure and more humane, and the inclusion of some relaxed moments drive the libretto away from the naturalistic style used by Crabbe, who aimed "to describe the depraved, the abject, diseased and neglected" (Francis Jeffrey, quoted in Bewell 2005, p. 637); Britten's musical rewriting has therefore been considered by some critics as "a Romantic rewriting of Crabbe" (ibidem).

-Love is more than a conventional requirement of opera in the libretto: musically, it produces some of the most beautiful songs in the score, Ellen's arias and her duets with Peter; dramatically, love is assigned the role, in Ellen's incarnation, of mediator between the accusing borough and Peter. It is only at the end, when she is aware that the third boy has also died, that she realizes she cannot save him and has to give in to the borough's condemnation. The failure of Ellen's love to redeem Peter and the latter's reluctance to propose to her until he has worked and earned enough suggest that it is rather the impossibility of love that the opera focuses on, something which is also hinted at in the proxemics of the text: "Love is continually gestured at, but people rarely touch one another, the isolating gap separating characters being often too great for even hands to meet" (Bewell 2005, p. 643). This failure on both Peter's and Ellen's sides to achieve social respectability for the fisherman, together with the latter's refusal to defend himself before the court or the borough, his unscrutable silences throughout the opera and his (perhaps melancholy) recalling of the 
first apprentice in II.ii have all been widely interpreted - among other signs - as hints on Britten's self-declared homosexuality, ${ }^{10}$ which would also be reflected in the protagonist's "otherness", his "unclassifiable" nature for a society then marked by tribal values and varying hypocrisy. Nevertheless, this must not be taken as a clearly sympathetic view on the part of the composer towards his character, as Spiegelman warns (2008 [1986], p. 10): "It is tempting of course to see in Grimes Britten's own projection of the homosexual as outsider, and to consider the Britten-Pears-Forster collaboration an attempt by three homosexual artists to elicit sympathy for that outsider, but yielding to this temptation overlooks the uncriminal but genuine unattractiveness of the hero."

-Peter is certainly much more complex in the libretto than in the poem. Britten and Slater created a tragic and highly modern figure, contradictory and deeply ambiguous, an outcast who does not really want to be one, who must be seen as both sinner and victim, suspicious but not clearly guilty (he does not seem to have killed his apprentices, but he has obviously done nothing for their safety or well-being either). Composer and librettist move away from Crabbe's perverse criminal and turn Peter into an outcast, ${ }^{11}$ who is perceived by the community as a different and troubling figure. In both works the protagonist is violent, but in the musical drama although his violence extends to Ellen, whom he strikes in what is probably the climax of the opera (II.i), he can also be tender, albeit very occasionally, and is an outcast who does not really want to be one. He is not a likeable character, though: his arrogance, unsociable and elusive nature, and cruelty to Ellen and the children turn him into a difficult character to sympathize with. But somehow the opera seems to ask for tolerance, and Spiegelman claims that it is the music that achieves this (2008 [1986], p. 14). In the end, the ambiguity of Britten's Grimes leaves us with an uneasy feeling: "Peter Grimes makes a final judgment of its hero an impossibility, because it prohibits us from knowing him" (ibidem).

\footnotetext{
${ }^{10}$ See for instance Crawford (2013).

${ }^{11}$ Spiegelman, however, opposes clear-cut distinctions between the poem's and the opera's Grimes: “Crabbe's Peter may be a little less, and Britten's a little more culpable” (2008 [1986], p. 2).
} 
-The borough acquires a character's status in the opera, as Peter Grimes's antagonist. Crabbe's censure of the townspeople's attitude in his poem is for their indifference and passivity about Peter's ill-treatment of the boys. The repetition of "none" in the poem is Crabbe's verbal means to censure the community's sin of omission, as Dennis remarks (2009, p. 5):

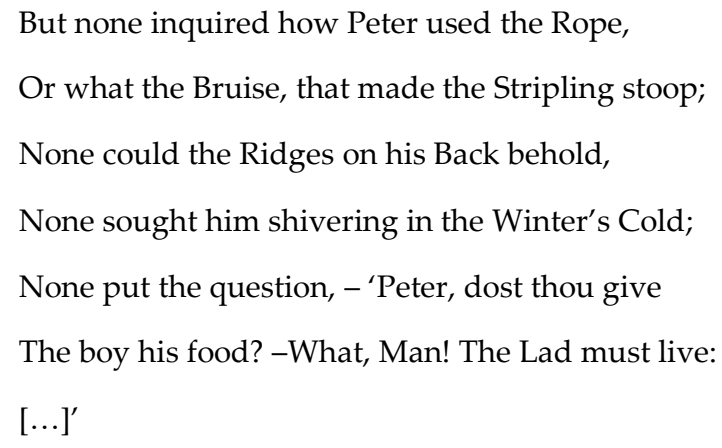

This silent complicity is turned into veiled but constant accusations in the opera: "Grimes is at his exercise!", the only phrase Slater took literally from the poem, meaning he is abusing his apprentice, is heard repeatedly from Act II; this becomes clear persecution towards the end, when the chorus rancorously sings "Him who despises us we'll destroy" (Act III.i). Gossip and rumours characterize the Borough and accompany Peter everywhere. In both poem and opera Peter becomes progressively deranged, due to his obsession for work, his solitude and, particularly in the opera, "the social power of gossip" (Bewell 2005, p. 644), which drives Peter to his final suicide and some have read as an allegory of homosexual persecution. Britten seems to have intended to make us reflect on society's responsibility, and he has made Peter and the Chorus, i.e. the villagers - who have passed their guilty verdict against the fisherman from the beginning - the two main protagonists of his opera. In fact, the composer once described 
Peter Grimes as "an opera about the community" (quoted in Ashby 2013, p. 15). ${ }^{12}$

d. Using the music

Britten makes full use of his music to explore and convey the deeper meanings, making his vocal and instrumental scores closely reflect the characters' feelings and actions, as well as his own intentions. For instance, Ellen's important role is reflected in the fact that she gets one of the most beautiful arias, "Embroidery in childhood" (III.i). The apprentices, by contrast, are silenced in the opera (as opposed to the poem, in which we hear their voices), perhaps thus rendering them more helpless: the first two have died before the musical drama starts and all we hear from the third and only boy we see on stage is his scream as he falls off the cliff in II.ii (an orchestral crescendo revealing his fatal fall). But a viola solo seems to stand for the boy's voice, its melancholy sound being heard after Peter strikes Ellen and the child runs away from him in II.i, echoing again at the end of II.ii, when Balstrode observes the apprentice's clothes in the empty hut, after the fall (Cortizo 2011, p. 63, p. 66). This cohesive role of music is prominent throughout the whole score: for example, Peter's monologue in III.ii. ("Steady. There you are. Nearly home!") recalls his whole story in the opera with both musical and verbal echoes of past moments (Spiegelman 2008, p. 18).

The music is certainly used by Britten to convey his view of the villagers: on the one hand, their collective responsibility in Grimes's annihilation is also expressed by the music, through the regular harmonies and rhythms in the melodies of their arias, representing them as a uniform community (Ashby 2017, p. 15); this has sometimes been reinforced on the stage, as in Willy Decker's emblematic 2004 production for the Royal Opera House, in which the Borough is presented as a compact mass which moves like a huge and threatening wave. ${ }^{13}$ On the other hand, the Borough seems to also deserve a sympathetic view, which the composer himself stated

\footnotetext{
${ }^{12}$ Britten maintained, as Dennis recalls $(2009$, p. 2): “The more vicious the society, [...] the more vicious the individual".

${ }^{13}$ See pictures at https://www.roh.org.uk/news/peter-grimes-a-short-guide. Accessed on May 122019.
} 
when he later recalled: "In writing Peter Grimes, I wanted to express my awareness of the perpetual struggle of men and women whose livelihood depends on the sea" (quoted in Spiegelman 2008, p. 11). And it is mainly through the music that this more positive attitude is conveyed. The Chorus is given some of the most memorable moments in the score: the opening chorus, the storm ensemble, or the ensembles in Acts II and III, and the opera's final words.

The end of the opera encapsulates many of the issues discussed so far: Peter's madness before he dies is dramatized in his final monologue with his responses to the chorus's imprecations, alone on the stage and at times repeating his own name - "Grimes! Grimes! Peter Grimes" - against the silence of the orchestra. A significant change is introduced now by Britten in his transmutation of Crabbe's poem: whereas the original Grimes died, mad and terrified, in an almshouse's bed, the opera's protagonist is granted a more heroic, operatic, death - albeit offstage, with Peter committing suicide by sinking his own boat (following his friend Balstrode's advice), finally at one with the open sea.

The last strains take us back to the music evoking the sea at the beginning of the opera. A boat has sunk but the borough resumes its daily life, seemingly oblivious to Peter's tragic end, singing a last hymn to that threatening, but indispensable, element:

$$
\begin{aligned}
& \text { In ceaseless motion comes and goes the tide, } \\
& \text { Flowing it fills the channel broad and wide, } \\
& \text { Then back to sea with strong majestic sweep, } \\
& \text { It rolls in ebb yet terrible and deep. }
\end{aligned}
$$

\section{Translating opera: Peter Grimes in Spanish sub/surtitles}

The process of transmutation illustrated above with Peter Grimes may be accompanied by that of "translation proper" in the genesis of an opera, as is the case with many pieces of musical drama deriving from literary texts which had been created in a different language and cultural system. Trans- 
lation may also take place after the production of a musical text: indeed, vocal music, from various genres, has travelled widely in translated form (see Low 2017 and Mateo 2012). Translation is pervasive in the world of music, despite the fact that its impact is something not many people are aware of.

The challenges involved in rendering a musical text into a new language derive, on the one hand, from the close relationship between words and music and the need to interpret the original lyrics or libretto - and convey the target text - within the musical framework; and, on the other hand, from the technical constraints imposed by the translation modality in question. Linguistic and textual issues naturally also have a say in the process: each language has its own sonority, which has implications for the effect produced by the adjustment between the music and the original text and is particularly relevant in sung translation, when a new text in a different language, with its own rhythmical patterns and sounds, is substituted in the singing. Textual characteristics of song lyrics and librettos, as oral expressive texts, may also turn their rendering into a foreign language difficult, even in those translation modalities which seem less demanding (see below). In his detailed analysis of lyrics, Low quotes as their common features (2017, pp. 20-37): phonic figures of style such as rhyme, repetitions, onomatopoeia, alliteration; the inclusion of highly poetic language and emotionally charged vocabulary; the use of metaphor, ambiguity, irony, or humorous and narrative elements; cultural issues (eg. references to the extralinguistic situation, parody of earlier songs, musical allusions); and nonstandard language (e.g. colloquialisms, dialect, foreign phrases, etc) or archaisms (depending on the genre in question).

Different options are available to convey a musical text across linguistic boundaries, and the choice will be determined by factors such as the purpose of the translation, the specific needs of its user(s), the musical genre the text belongs to, the context of reception of the target text, the channel of communication through which it will be conveyed, and sometimes also 
sociocultural, artistic, economic and political reasons. ${ }^{14}$ Despite the fact that all song types present the components of word, music and performance, there is hardly any room for an "all-purpose translation", as Low insists (2013, p. 78), given "the variety of specific purposes for which a translation might be sought" for a musical text (2006, p. 511) - clearly in line with functionalism in translation theory (see, for instance, Nord 1997). Low lists the following five main functions for song translation (2006, p. 512):

1. To be sung in the target language

2. To be spoken as an introduction to the original song

3. To be read in a recital program or a CD insert

4. To be studied by the singer preparing to perform the song in the source language

5. To be displayed as surtitles while the song or opera is being performed, or as subtitles on a videoed performance.

These options naturally have their own characteristics and requirements and involve different translation modalities: sung translation in 1 (to be delivered on a stage or through dubbing), gist translation to be delivered orally in 2, written translation for different reading contexts in 3 and 4, and written translation to be projected on different types of screen and in different circumstances in 5. As a result, a translation produced through one modality for a particular purpose will not normally be suitable for another purpose or type of reception context. ${ }^{15}$

The various functions, together with the challenges, possibilities and constraints that the corresponding modality involves, will obviously produce variations on the musical source text, which will be added to by the specific translator's (or translating team's) personal choices, as will be illustrated with the textual choices made for Britten's opera in the Spanish surtitles and subtitles examined below.

\footnotetext{
${ }^{14}$ See Low (2006) for an account of the general factors; and Mateo 2001 as well as Mateo 2008 for the study of sociocultural, artistic and economic reasons affecting the translation of opera and musicals.

${ }^{15}$ For a detailed analysis of the characteristics of each modality, see for instance Low 2017.
} 
Surtitling and subtitling, the two modalities covered in function number 5 above, cannot only claim to be the commonest translation modalities for opera today - the former for the reception of live performances in opera houses, the latter for DVD recordings - but they are also probably the most suitable ones for works by composers like Britten, who deeply cared about the words of his vocal music creations as well as about his audiences' understanding. This implies, on the one hand, that some sort of target version seems advisable when his works are performed for audiences who do not share their language - as Low tells us, the composer himself, used to have English translations printed in the programmes of productions for which he had chosen foreign poems to be sung in their original languages (2013, p. 70); on the other hand, Britten's special care over his choice of texts, their sounds and rhythmical patterns, as well as the intricate word-music relationship he achieved in his vocal music creations all seem to discard sung translation as a suitable modality in his case, since it entails changing the original adjustment. Besides, as Low also observes (2013, p. 73), "[w]ith Britten [...], there is little place for singable translations, since most singers of Art Song want to perform the original words, with the very vowels, consonants and meanings with which the composer wrestled."

Nevertheless, unlike the other types of written translation (corresponding to function number 3 above), surtitling and subtitling involve a series of constraints, deriving from the new channel through which the libretto is conveyed in the target version (a screen above the proscenium or behind the seats in the case of surtitling, and the bottom part of a television, cinema or computer screen in subtitling) as well as from the synchronization with the sung performance which is required of projected captions (see, for instance, Low 2017, Mateo 2007 and Virkkunen 2004). Both modalities are therefore marked by time and space constraints, which in turn entail the need for concision, clarity, ease of understanding and coherence with the particular production, so that the titles may be as unobtrusive as possible. These will all affect the textual choices taken by sur/subtitlers, and variations on the original libretto, as well as between the different versions, inevitably occur. 
My own surtitles for the opera house in my hometown, Oviedo, which boasts one of the oldest opera seasons in Spain and staged Peter Grimes during the 2011-2012 season in a joint production with the English National Opera and the Belgian Der Vlaamse Opera, will provide some examples from this modality; while the recording of the open air production at the 2013 Alderburgh Festival, Peter Grimes on Aldeburgh beach, with the Britten-Pears orchestra and the Chorus of Opera North, will illustrate the corresponding Spanish subtitles.

Condensation of the text and the choice of naturalness (see Mateo 2012, p. 118) are shown in both the surtitling and subtitling versions of the following excerpt (I.i), in which Peter dreams of a future life that will allow him to counteract his townpeople's harsh treatment of him (different lines are separated by /, both in the source and target texts, while // mark the boundaries between different captions):

These Borough gossips / listen to money, / only to money. / I'll fish the sea dry, / sell the good catches. / That wealthy merchant / Grimes will set up / household and shop; / You will all see it! / I'll marry Ellen!

(Surt.): // Estos cotillas nada más / que escuchan al dinero. // Dejaré el mar sin peces, / los venderé. // El rico Grimes tendrá casa y tienda: ¡ya lo veréis! // ¡Y me casaré con Ellen! //

(Subt.):// Esos cotillas solo escuchan al dinero. // ¡Dejaré el mar sin peces! // Ø // El rico comerciante Grimes tendrá / casa y negocio propio. ¡Ya lo veréis! // ¡Me casaré con Ellen! //

As can be seen, repetitions (eg. "money" above) are commonly eliminated (Mateo 2012, p. 118), and complex phrases (like the subject "That wealthy merchant / Grimes") are condensed, as are some semantic units which may be inferred from a neighbouring one (e.g. "sell the good catches", which has been deleted in the subtitles). The condensation has also affected the reference to the Borough here, deleted in both versions since the contextualisation it provides for the gossips is made clear with the 
demonstratives used in both Spanish texts. Unfortunately, however, the physical and moral presence of the Borough and its effect on Grimes's life have been slightly diluted in both Spanish versions because of the subtitlers' and my own decision to introduce lexical variation whenever this term appears in the libretto: la(s) gente(s), el pueblo, el municipio, todos, etc. have been used instead of burgo, since this etymological correspondent has different connotations and usage in Spanish.

"Borough" has also disappeared in the next sentence, when Peter first introduces his complaint of the villagers' liking for rumours and gossip; both the surtitles and subtitles have typically neutralised the topicalised subject of the source text:

They listen to money, / these Borough gossips.

(Surt.):// Los cotillas escuchan solo al dinero. //

(Subt.):// Esos cotillas solo escuchan al dinero. //

A simple, neutral, syntax is often preferred in these translation modalities in order to facilitate ease of understanding and quick reading (Mateo 2012, p. 118). This is frequently done at the expense of tone and style, although both these versions of Peter Grimes have managed, in general, to preserve each character's style (colloquial, poetic, humorous, legalistic, etc.) and the overall tone of each scene (intimate, painful, violent, gossipy, etc.).

One and the same feature, however, can be fulfilled with various textual choices, as the two versions provided for the villagers' accusation "Grimes is at his exercise!" (II.i) illustrate: both convey the naturalness and negative content of the English expression with Spanish idiomatic (equally "ambiguous") phrases, but the translation provided in the surtitling, "¡Grimes ha vuelto a las andadas!", insists on the repetitive nature of the protagonist's ill-treatment of his apprentices, while the subtitles' “ $i$ Grimes está haciendo de las suyas!" seems to focus more on the present time and is perhaps slightly more negative. 
The type of reception produced by the channel of communication of these translation modalities - in which the source text is not replaced by the target version and the latter is received simultenously with the performance - may sometimes influence textual choices, as the following excerpt, when Peter recalls the deaths of his apprentices (III.ii), illustrates:

The first one died, just died... / The other slipped, and died... / And the third will... / "Accidental circumstances".

(Surt.):// El primero murió, simplemente murió.../ El segundo resbaló, y murió... // Y el tercero... “causas accidentales". //

(Subt.):// El primero murió, así, sin más. / El segundo resbaló, y murió... // Y el tercero... "circunstancias accidentales". //

Peter's phrase "Accidental circumstances" is heard very clearly in the singing, coming after a slight pause; both the surtitles and especially the subtitles seem to have opted for a more literal translation here, so that the caption reflects the English expression coming from the tenor's voice more closely, at the expense of both the economy and naturalness which would have been achieved with the commoner Spanish phrases "por accidente" or "fue un accidente".

All translation processes are a question of priorities and choices, and the challenges posed by these two modalities as well as the abovementioned criteria usually adopted in them may be negotiated in various ways by different sur/subtitlers. For instance, unlike the surtitles, the subtitles in the DVD examined have not translated any off-stage singing (mostly coming from the chorus, the Borough, in this opera). The criterion in this regard seems to have been to prioritize the unobtrusiveness of the captions, focusing on the singer on stage, at the expense of the overall effect produced by the contrast between the off-stage and on-stage singing: for instance, between the hymn and prayers heard from the chorus in the background and Ellen's sweet and melancholy melody in her famous scene with Peter's new apprentice (II.i), when she evokes for us the hardships of 
British apprentices in the 19th century (before she discovers the boy's bruise); or between the sinister and menacing march coming from the chorus and Peter's lyrical recitative and dreamy singing in II.ii.

Another example of different ways in which the criteria can be met is provided by the slightly divergent segmentation of the libretto shown by the surtitles and subtitles analysed, which in turn responds to different ways of managing time. An overview of all the captions in each of these Spanish versions seems to reveal greater attention given to units of meaning and closer synchronization with the music in the subtitles, while my surtitles, in comparison, seem to give preference to economy in terms of the distribution of the text. This means a greater number of titles in the subtitles - therefore more reading effort required - and the occasional loss of dramatic effect in the reception of the surtitles, as is illustrated in the next example, in which Peter recalls his former aprentice's death (I.i):

Then home / among fishing nets / alone, alone, alone / with a childish death!

(Surt.): // ¡Volví a casa entre redes / solo y con un chico muerto! //

(Subt.): // Después el regreso entre las redes de pesca //

// solo //

// y con un chiquillo muerto. //

His loneliness and shock at having to return with a dead child are more vividly conveyed in the segmentation offered by the subtitles, which have made up for the compression of "alone" by placing "solo" in a separate title showing exact synchronization with Peter's repetition of the English adjective.

One must not forget, however, that surtitles and subtitles are nonautonomous texts (see Mateo 2007 and Virkkunnen 2004), and can only be judged in terms of their functional nature - as an often-crucial aid to understanding - and the way in which they complement - rather than interfere with - the semiotic complexity of the performance so as to enhance the 
audience's or viewer's enjoyment of the operatic experience. The great variety of elements involved in an opera production and of the factors to be considered for effective surtitling and subtitling imply that creators of these texts will readjust their decisions and priorities to the different scenes or instances of the performance; and they will do so according to their own criteria - and often in agreement with other agents involved, such as the opera house's artistic director, in the case of surtitles. Thus, for the Chorus's final song, "as the curtain slowly falls" at the end of Peter Grimes, the subtitlers seem to have opted for concision and easy reading on this occasion, while my surtitles now show greater attention to style and rhythm:

In ceaseless motion comes and goes the tide, / Flowing it fills the channel broad and wide, / Then back to sea with strong majestic sweep, / It rolls in ebb yet terrible and deep.

(Surt.):// En su incesante vaivén, / la marea viene y va. // Sube, y llena hasta arriba el canal. // Luego vuelve al mar / con un giro fuerte y majestuoso. // Y así baja, aún terrible y profunda. //

(Subt.):// La marea va y viene sin cesar. // Cuando viene, llena los canales. // Después regresa majestuosa al mar. // Un reflujo terrible y profundo. //

\section{Concluding remarks}

The connections between literature, music/opera, and translation are rich, complex and often controversial. This paper has examined some of them by making special mention of Benjamin Britten and looking at the processes of transmutation - from literary text to musical genre - and "translation proper" - in written target versions of a musical piece, his opera Peter Grimes. Both processes show variations produced either by the new medium or by the adaptor's/translator's/surtitler's/subtitler's personal choices, and Britten's work has helped to illustrate the alterations produced in those journeys across genres and across languages. Peter Grimes is also a good exam- 
ple of how musical texts often have their origin in literary texts and, as Robert Stam said of film adaptations, "are caught up in the ongoing whirl of textual reference and transformation, of texts generating other texts in an endless process of recycling, transformation, and transmutation, with no clear point of origin" (quoted in Zatlin 2005, p. 150).

\section{References}

ARKUS, Mario. La ópera británica entre Purcell y Britten, o arreglemos el teléfono. Filomúsica. Revista Mensual de Publicación en Internet v. 37 (February), p. 1-14, 2003: http://www.filomusica.com/filo37/obritanica.html; and v. 38 (March), p. 1-11, 2003: http://filomusica.com/filo38/opbrit2.html. Accessed May 122019.

ASHBY, Arved. Peter Grimes and the "Tuneful Air". In: RUPPRECHT, Philip (Ed.) Rethinking Britten. Oxford Scholarship Online, 2013, https://www.oxfordscholarship.com/view/10.1093/acprof:oso/9780199794805.001. 0001/acprof-9780199794805-chapter-4. Accessed May 122019.

AUDEN, W. H. Prose. vol. III: 1949-1955. Edited by Edward Mendelson, Princeton: Princeton U. P., 2008.

BERNHART, Walter (Ed.) 2006. Word and Music Studies. Selected essays on Opera by Ulrich Weisttein, Amsterdam/New York: Rodopi, 2006.

BEWELL, Alan. On the Margin of Sea and Society: Peter Grimes and Romantic Naturalism. In: University of Toronto Quarterly v. 74, n. 2 (Spring), p. 636-647, 2005.

BROWN, Calvin. Theoretical Foundations for the Study of the Mutual Illumination of the Arts. In: CUPERS, J-L.; \& WEISSTAN, Ulrich (Eds.) Word and Music Studies: Musico-Poetics in Perspective, Calvin S. Brown In Memoriam. Amsterdam: Rodopi, 2000 [1984], p. 281-295.

CORSE, Sandra. Opera and the Uses of Language: Mozart, Verdi, and Britten. Rutherford, London and Toronto: Associated University Press, 1987.

CORTIZO, Maria Encina. Peter Grimes. Guía para la audición. In: Opera Oviedo (Ed.) Peter Grimes, LXIV Temporada de Ópera de Oviedo 20112012, Oviedo, 2011, p. 50-69. 
CRAWFORD, Lucas. 'A child is being beaten': Peter Pan, Peter Grimes, and a queer case of modernism. In: ESC v. 39, n. 4 (December), p. 33-54, 2013.

DEGOTT, Pierre. Early English Translations of Italian Opera. In: STOCKHORST, Stefanie (Ed.) Cultural Transfer Through Translation. The Circulation of Enlightened Thought in Europe by Means of Translation. Amsterdam/New York: Rodopi, 2010, p. 185-207.

DENNIS, Ian. The Pastoral Victim's Progress: Crabbe to Britten. In: Anthropoetics v. 14, n. 2 (Winter), 2009, http://anthropoetics.ucla.edu/ap1402/1402dennis/ Accessed on May 122019.

DESBLACHE, Lucile. The turn of the text? Opera libretto and translation: appropriation, adaptation and transcoding in Benjamin Britten's The Turn of the Screw and Owen Wingrave. In: Traducció creativa. Quaderns de Filología. Estudis Literaris, v. XIII (special number edited by Cecilia LÓPEZ \& Jesús TRONCH), p. 105-123, 2008.

HALLIWELL, M. Opera and the Novel: The Case of Henry James. Amsterdam/New York: Rodopi, 2005.

JAKOBSON, Roman. On Linguistic Aspects of Translation. In: VENUTI, Lawrence (Ed.) The Translation Studies Reader. London \& New York: Routledge, 2000 [1959], p. 113- 118.

LOW, Peter. Song Translation. In: BROWN, Keith (Ed.) Encyclopedia of Language and Linguistics. v. 11, Amsterdam and Oxford: Elsevier, 2006, p. 511-514.

Purposeful Translating: The Case of Britten's Vocal Music. In: MINORS, Helen Julia (Ed.) Music, Text and Translation. London/New York: Bloomsbury, 2013, p. 69-79.

Translating Song. Lyrics and Texts. London \& New York: Routledge, 2017.

MATEO, Marta. Performing Musical Texts in a Target Language: the Case of Spain. In: Across Languages and Cultures v. 2, n. 1, p. 31-50, 2001.

Surtitling today: new uses, attitudes and developments. In: Linguistica Antverpiensia, v. 6/2007 (Special Issue: A Tool for Social Integration? Audiovisual Translation from Different Angles, edited by Aline Remael y Josélia Neves), p. 135-154, 2007. 
Anglo-American Musicals in Spanish Theatres. In: The Trans-

lator v. 14, n. 2 (Special Issue: Translation and Music, edited by Sebnem SUSAM-SARAJEVA), p. 318-342, 2008.

Music and Translation. In: Gambier, Yves; \& Van Doorslaer,

Luc (Eds.) Handbook of Translation Studies, vol. 3, Amsterdam: John Benjamins Publishing Company. 2012. p. 115-121.

NEWMARK, Peter. Art Song in translation. In: MINORS, Helen Julia (Ed.) Music, Text and Translation. London/New York: Bloomsbury, 2013, p. 5968.

NORD, Christiane. Translating as a Purposeful Activity. Functionalist Approaches Explained. Manchester: St. Jerome Publishing, 1997.

ROSMARIN, Léonard. When Literature Becomes Opera. Amsterdam: Rodopi, 1999.

SALZMAN, Eric \& DESI, Thomas. Text. In: SALZMAN, Eric \& DESI, Thomas. The New Music Theater. Seeing the Voice, Hearing the Body. New York: Oxford U. P., 2008, p. 78-95.

SCHMIDGALL, Gary. Literature as Opera. New York: Oxford U.P., 1977. SPIEGELMAN, Willard. Peter Grimes. The Development of a Hero. In: Imaginative transcripts: selected literary essays. Oxford Scholarship Online, 2008 [1986]), https://www.oxfordscholarship.com/view/10.1093/acprof:oso/9780195368130.001. 0001/acprof-9780195368130-chapter-5. Accessed May 122019.

SUÁREZ LAFUENTE, Maria Socorro. Peter Grimes. La translación artística: Intertextualidad músico-literaria. In: Opera Oviedo (Ed.) Peter Grimes, LXIV Temporada de Ópera de Oviedo 2011-2012, Oviedo, 2011, p. 12-20.

VIRKKUNEN, Riitta. The source text of opera surtitles. In: Meta v. 49, n. 1, p. 89-97, 2004.

WIEBE, Heather. Discovering America: from Paul Bunyan to Peter Grimes. In: Cambridge Opera Journal v. 27, n. 2, p.129-153, 2015.

ZATLIN, Phyllis. Theatrical Translation and Film Adaptation. A Practitioner's View. Clevedon: Multilingual Matters, 2005. 


\title{
Audiovisual reference
}

BRITTEN, Benjamin. Peter Grimes on Aldeburgh beach, filmed production at Aldeburgh Festival, June 2013; conducted by Steuart Bedford; directed by Tim Albery (screen director: Margaret Williams), Germany: ArtHaus Musik, 2013.

\begin{abstract}
Literary texts have often provided the source for musical texts, moving across genre and time boundaries, and interlinguistic translation has often added to the variations produced on those originally literary works in various forms of translation modalities. This paper discusses the intersections between music, literature and translation, focusing on opera and turning our attention to Benjamin Britten, whose work Peter Grimes serves to illustrate first the process of translation as transmutation, in its journey from poetry to opera piece, and then that of translating vocal music into a different language and communication channel, in the form of Spanish surtitles and subtitles.
\end{abstract}

Keywords: Literature; Opera; Musical translation; Transmutation; Subtitling; Surtitling; Benjamin Britten; Peter Grimes.

\section{Resumo}

As obras literárias foram frequentemente utilizadas como fontes para textos musicais, cruzando os limites de gênero e de tempo. Já a tradução interlinguística comumente aumentou as variações produzidas nessas obras, originalmente literárias, por meio de diferentes modalidades tradutórias. Ao discutir as intersecções entre música, literatura e tradução, este artigo se concentra na ópera e volta sua atenção para a obra Peter Grimes, de Benjamin Britten, que permite ilustrar o processo de tradução como transmutação, na sua viagem da poesia para a ópera, bem como o de tradução de música vocal em diferentes línguas e canais de comunicação, sob a forma de legendas em língua espanhola.

Palavras-chave: Literatura; Ópera; Tradução musical; Transmutação; Legendagem; Benjamin Britten; Peter Grimes. 